Received: 30 July 2018

Accepted: 14 October 2018

Online: 17 October 2018

Authors:

I. V. Anyiam.

Department of Microbiology, Federal University

Otuoke, Nigeria

T. O. Ikpesu $\bigotimes$

Department of Biology, Federal University Otuoke, Nigeria

$\bigotimes$ tomohwofasa@yahoo.com

Emer Life Sci Res (2018) 4(2): 1-10

E-ISSN: 2395-6658

P-ISSN: 2395-664X

DOI: https://doi.org/10.31783/elsr.2018.420110
Research Article

\section{Microbiological quality and biochemical composition of water snail (Pachymelania byronensis) of lower Niger River basin}

\author{
Ifeoma Vivian Anyiam, Thomas Ohwofasa Ikpesu
}

\begin{abstract}
Pachymelania byronensis is a mollusk that is very abundant in the Niger Delta ecological zone, Nigeria especially the lower region that has the brackish water. The meat of this gastropod serves as good source of protein to the inhabitants. Hence, its nutritional composition was investigated to ascertain its suitability for human consumption.

The snail samples were randomly hand-picked from their natural environment during August, 2017 to January, 2018 from wet and dry seasons. A total of 144 P. byronensis (24 per station) samples were used for this investigation. The total heterotrophic bacteria count was determined using standard pour plates method. Coliform count was determined using MacConkey agar, total Salmonella /Shigella counts was estimated using Salmonella/Shigella agar and total vibrio counts was determined employing Thiosulphate citrate bile salt sucrose agar. The isolates were identified with reference to Bergey's Manual of Determinative Bacteriology. The foot muscle and viscera were used for the proximate estimation of nutritional composition.

The bacteriological load in the P. byronensis revealed that there were variations in the occurrence of different groups. Salmonella /Shigella counts was highest $1.96 \pm 3.45 \times 10^{3}$ (cfu/100mL) followed by Total vibrio counts $1.66 \pm 3.13 \times 10^{3}(\mathrm{cfu} / 100 \mathrm{~mL})$. Total heterotrophic bacteria counts was $1.63 \pm$ $4.97 \times 10^{3}(\mathrm{cfu} / \mathrm{m})$ and least was Coliform counts $1.30 \pm 3.70 \times 103$ $(\mathrm{cfu} / 100 \mathrm{~mL})$. The nutritional status showed that the snail is a valuable source of seafood that can meet the nutritional requirements of man.

The findings revealed that human activities might have influenced the microbial load in the Rivers, and the nutritional status of snail revealed that it could be used as food for humans, which would go a long way in maintaining the nutritional balance of human diet.
\end{abstract}

Keywords biochemical characteristics, microbiological load, Pachymelania byronensis, total heterotrophic bacteria

\section{Introduction}

The rapid increase in human population and the desire for quality food necessitate the search for new resources to accommodate the challenges. Hence, the need to explore new potential sources of food especially seafood protein and to improve the existing ones becomes inevitable and the demand for fisheries product increases every year [1], and molluscs have been recognized as a high quality nutritious food source and many species are considered as culinary delicacies [2]..

Numerous experiments have reported relatively high protein levels in mollusc flesh, including abalone Haliotis diversicolor [3] and the oyster 
Crassostrea gigas [4-5]. The nutritional worth of mollusc flesh lies not only within the high quality of protein, but also in its moderately low lipid content and high proportion of PUFAs [6]. Molluscs are known to contain a wide variety of PUFAs, some of which are considered as essential fatty acids that humans cannot synthesize and must be obtained from food [7]. Amongst the PUFAs, long-chain omega-3 fatty acids, such as eicosapentaenoic (EPA), docosapentaenoic (DPA) and docosahexanoic (DHA), are thought to play beneficial roles in a healthy diet. The balanced intake of omega-3 (n-3) and omega-746 (n6) fatty acid can help prevent cardiovascular diseases [8-9], coronary heart diseases, arthritis [10] and other inflammation [11].

The largest quality component in mollusc flesh is the moisture that can be as high as $80 \%$ of the fresh wet weight. The inorganic mineral content (ash weight) ranges between 1 to $17 \%$ of the fresh wet weight [12]. Molluscs meat has been recommended in some dietary regimes for its relatively high protein content [5]. Marine gastropods can potentially be used as an alternative to traditional protein sources (such as beef/ chicken/fish) for human consumption.

Pachymelania byronensis is gastropod molluscs and adapted to low salinity. It is a widespread species with no known major threat. It is distributed throughout the world, and predominantly found in West Africa Coast and is cosmopolitan in the entire Niger Delta ecological zone. Till now, there has been little study on $P$. byronensis with regard to its microbial health status, heavy metal composition (detritus feeders) and nutritive value for human consumption. Therefore, the objective of this research is to determine the bacterial contamination status and nutritional composition of $P$. byronensis from brackish water of Niger River basin. As per the available literature, this was the first study to quantify the nutritional composition and health status of this common snail in this region.

\section{Methodology}

\section{Description of the study area}

Fish Town Rivers is an offshoot of Sangana River (Figure 1). This river is severely affected by human activities that re-defined its natural habitat. The water is also quite variable as marine tides go high and low, consequently increasing or decreasing the salinity of water. Hence, the living forms that stay in and are dependent on the water must also adapt according to salinity changes and several other physical aspects of water including temperature, water density, $\mathrm{pH}$ balances, buoyancy, wave action and changes in nutrients.

The stations chosen (Angalabiri, Better land and Farm camp) along the river were the places where $P$. byronensis was dominant. They were found attached to substrates at the edge or in the shallow region where they experience fluctuating tides.

\section{Hydro-chemical parameters determination}

Salinity, temperature, dissolved oxygen, total hardness, $\mathrm{pH}$, turbidity, total dissolved solid, chemical oxygen demand, nitrate and phosphate of different stations within the fish Town Rivers were measured as hydrochemical parameters. Samples were monthly collected and parameters were followed using standard method [13].

\section{Salinity}

Salinity was measured using an electrical conductivity meter (EC meter). The device determined the salinity of a sample by sending an electrical current through the sample, and measured the resistance of the sample towards the flow of the current. For accurate reading, the EC meter that measured up to $19.99 \mathrm{mS} / \mathrm{cm}$ $(19.99 \mathrm{ds} / \mathrm{m})$ was used.

\section{Temperature}

Mercury-in-glass thermometer was used to measure the temperature of the water. The thermometer consisted of a uniform-diameter glass capillary that opened into a mercury-filled bulb at one end. The assembly was sealed to preserve a partial vacuum in the capillary. Mercury expanded and rise in the capillary on temperature increase. The unit of measurement was $0^{\circ} \mathrm{C}$. 


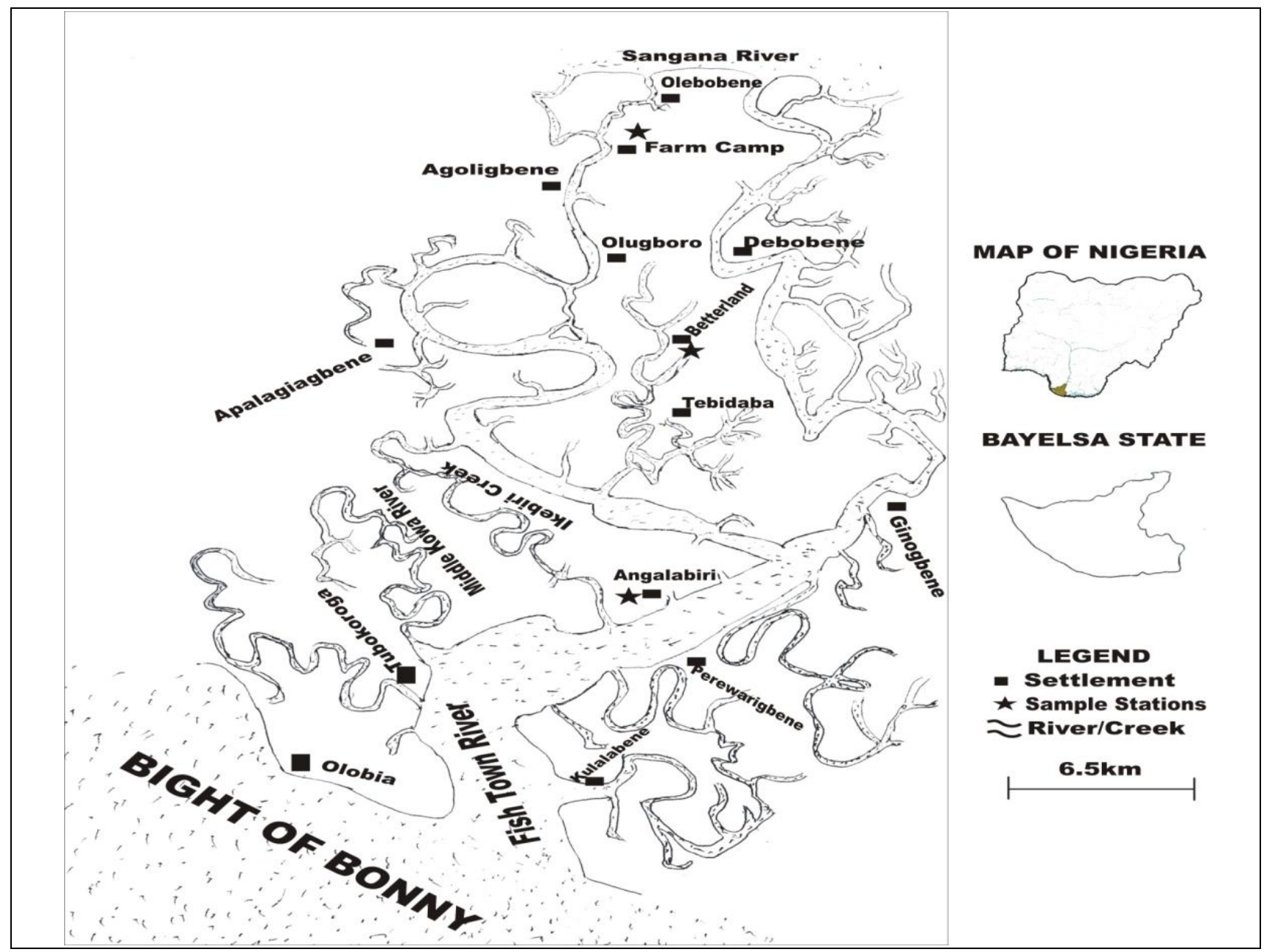

Figure 1. Map of the study River showing the sampling stations

Dissolved oxygen

DO was determined using a "Mettler Toledo" (DO model 90.71). The probe was inserted into the sample container containing the different treatments and the readings were taken. The unit of measurement was $\mathrm{mg} / \mathrm{L}$

\section{Total hardness}

Total hardness was measured by titration using $0.02 \mathrm{~N} \mathrm{H}_{2} \mathrm{SO}_{4}$ (aq) against $25 \mathrm{ml}$ of test solution using two drops of methyl orange as indicator. It was calculated by substituting the titre value into the equation below.

$$
\text { Total alkalinity }=\frac{\text { Titre value }(\mathrm{ml}) \times \mathrm{N} \times 50 \times 1000}{25 \mathrm{ml}(\text { volume of test solution used })}
$$

(The unit of measurement is $\mathrm{mg} / \mathrm{L}$ )

\section{$p H$}

The water $\mathrm{pH}$ was determined in situ in each of the aquarium with a $\mathrm{pH} /$ conductivity / TDS meter (Hanna Products, Portugal). This was achieved by dipping the end of the electrode into the text solution and the mode button was selected to give reading for the desired parameter. 


\section{Turbidity}

Turbidity values were measured using hand held turbidity meter. The meter was calibrated using standard samples from the meter manufacturer.

\section{Total dissolve solid}

TDS combines the sum of all ion particles that are smaller than 2 microns $(0.0002 \mathrm{~cm})$. It was measured by gravimetry method.

\section{Chemical oxygen demand}

The COD was calculated using the formula-

$$
\operatorname{COD}(\mathrm{mg} / \mathrm{L})=((\mathrm{B}-\mathrm{A}) * \mathrm{~N} * 800) / \mathrm{D}
$$

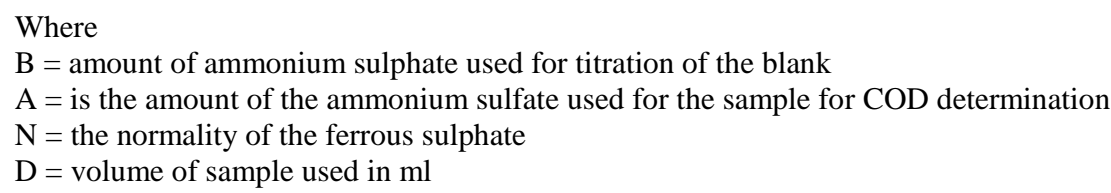

\section{Nitrate}

Nitrate was measured using an Ozonation technique where nitrite was quantitatively oxidized to nitrate. Nitrite was determined using sulfanilic acid and alpha-naphthylnmine. The color developed was read in a Beckman DU spectrophotometer at a wavelength of $520 \mathrm{~m} \mu$. One-centimeter cells were used for concentrations greater than $10 \mathrm{~m} \mu$ and $10 \mathrm{~cm}$ cells for lower concentrations. Nitrate was reduced by hydrazine and analyzed for the nitrite produced using a wavelength of $524 \mathrm{~m} \mu$ and 1-cm cells for concentrations greater than $5 \mathrm{~m} \mu$. Within the accuracy of the method, there was a linear relationship between optical density and added nitrite or nitrate up to concentrations of $60 \mathrm{~m} \mu$.

\section{Phosphate}

Phosphate was determined using the Hanna HI 736 pocket spectrophotometer. The Hanna Instruments HI 736 ultra-low range phosphorus checker has a range from 0 to $0.20 \mathrm{mg} / \mathrm{L}$ ( 0 to $200 \mathrm{ppb}$ ). It is a batteryoperated fixed wavelength $(525 \mathrm{~nm})$ spectrophotometer that uses a light-emitting diode light source and a silicon photocell light detector.

\section{Sample Collection}

The water snail ( $P$. byronensis) is one of the dominant aquatic organisms in this River; hence, collection was quite less rigorous. Sampling was done in such a way that the entire brackish water that were the snail habituates were considered for collection. Hence, three stations within the river were sampled; Angalabiri (station A), Betterland (station B) and Farm camp (station C). At the end of sampling periods, the average were taken and comparison were made. New latex gloves were worn when the snails were collected for processing. Snails with mean weight $(5.00+0.10 \mathrm{~g})$ and length and $(2.10+0.13 \mathrm{~cm})$ were hand-picked from the brackish water environment from August, 2017 to January, 2018, depicting wet season (August October) and dry season (November - January). A total of 144 P. byronensis (24 per station) were sampled for this investigation. At the end of each sampling period, they were collected in a sterile bag placed in an ice cooler to maintain a temperature of approximately $4^{\circ} \mathrm{C}$, and transported to the biology laboratory in the Department of Biological Sciences at Federal University Otuoke, where they were washed with potable water and sterilized (70\% ethanol). They were randomly divided into two portions (with proper identification for different examination) and kept in well ventilated aquaria for each analysis. 


\section{Microbiological analysis}

The microbiological profile was determined according to APHA method [13] as modified by Maturin and Peeler [14]. The foot muscle and viscera were mechanically extracted. Ten gram of meat was mixed with 90 $\mathrm{ml}$ of Ringer solution and well homogenized for 5 minutes.

Total heterotrophic bacteria counts was determined using standard pour plates method. Coliform count, total Salmonella /Shigella count and total vibrio counts was determined using MacConkey agar, Salmonella/Shigella agar and Thiosulphate citrate bile salt sucrose agar, respectively. The bacterial plates were incubated at $37^{\circ} \mathrm{C}$ for $36-48$ hours. The isolates were identified with reference to Bergey's Manual of Determinative Bacteriology [15].

\section{Proximate Analysis}

The foot muscle and viscera were mechanically removed from the shell and weighed using an analytical balance with precision of $\pm 0.0001 \mathrm{~g}$ (model ML 204/01; Mettler Toledo, Plainview, NY., U.S.A.). Briefly, the snail meat was digested in a mixture of $\mathrm{HNO}_{3}(25 \%)$ and $\mathrm{HCl}(75 \%)(1: 3$, v/v) subjected to hot-block. Elemental concentrations were determined on a wet weight basis and analyzed on an inductively-coupled plasma (ICP) spectrometer (NexION 300 D series) with ESI SC-FAST Auto Sampler (Perkin Elmer, Waltham, Massachusetts, U.S.A.). The digested meat was portioned and three replicates were analyzed; one portion was used for protein analysis, another for lipid and fatty acid analysis, and third for moisture and ash analysis. The protein content was determined using Lowry et al. [16], fat content was evaluated using Folch et al. [17], while the ash and moisture were determined using the standard AOAC procedure [18]. Total carbohydrate was obtained by subtracting the per cent amounts of crude protein, crude fat, moisture, and ash from $100 \%$.

\section{Statistical Analysis}

The data has been expressed as means \pm standard error. The Student's t-test and analysis of variance (ANOVA) were used to test for significance at the 0.05 and 0.01 levels of probability for the seasons and the stations, respectively.

\section{Results and Discussion}

\section{Physicochemical parameters of the fish Town Rivers}

The impact of human activities on natural ecosystem has changed the balance between biotic and abiotic factors that culminate into imbalance in the natural composition. The average physicochemical parameters of the Rivers sampled for both seasons showed $33.80 \pm 1.20 \%$ salinity; that was within the limit for the estuarine environment (35ppt) [19]. The temperature $(25 \pm 0.60){ }^{\circ} \mathrm{C}$ was fluctuating and less than the recommendation limit set by the various regulatory bodies [19].

Table 1. Range of the concentrations of the hydro-chemical parameters at three sites along the fish Town Rivers, Nigeria; sampled monthly from August, 2017 to January, 2018

\begin{tabular}{|l|l|l|l|l|}
\hline Parameters & Angalabiri & Better land & Farm camp & $\begin{array}{l}\text { DPR/FMEnv } \\
\text { Recommendation }\end{array}$ \\
\hline Salinity (\%) & $28.60-33.20$ & $24.40-38.10$ & $25.80-31.10$ & 35 \\
\hline $\begin{array}{l}\text { Water temperature } \\
\left({ }^{\circ} \mathrm{C}\right)\end{array}$ & $23.10-26.230$ & $21.50-25.20$ & $18.20-23.20$ & 30 \\
\hline $\begin{array}{l}\text { Total dissolve solid } \\
(\mathrm{mg} / \mathrm{l})\end{array}$ & $890-1140$ & $830-1110$ & $1100-1550$ & $2000(\mathrm{USEPA} ; 100-1000)$ \\
\hline Dissolve oxygen $(\mathrm{mg} / \mathrm{l})$ & $3-6$ & $4-6$ & $4-7$ & 5 \\
\hline $\begin{array}{l}\text { Chemical oxygen } \\
\text { demand (COD) }\end{array}$ & $32-43$ & $30-41$ & $30-43$ & 40 \\
\hline pH & $6.0-7.5$ & $7.0-7.8$ & $6.1-7.2$ & $6.5-9.2$ \\
\hline Turbidity & $4.2-11$ & $4.0-9.0$ & $6.1-10.0$ & 10 \\
\hline Phosphate (mg/l) & $4-7$ & $3-6$ & $5-7$ & 5 \\
\hline Nitrate & $17-21$ & $19-21$ & $17-23$ & 20 \\
\hline Total hardness & $300-450$ & $320-470$ & $350-508$ & $100-500$ \\
\hline
\end{tabular}


Total dissolve solid, total dissolve oxygen, chemical oxygen demand, phosphate, $\mathrm{pH}$, turbidity, nitrate and the total hardness were within the limit for aquatic life [20] (total dissolve solid; $1003 \pm 3.20 \mathrm{mg} / 1$ total dissolve oxygen; $5.70 \pm 0.20 \mathrm{mg} / 1$, chemical oxygen demand;39.20 \pm 0.50$) \mathrm{pH} ; 6.80 \pm 0.20$, turbidity; $7.20 \pm 1.12$, phosphate $\mathrm{mg} / \mathrm{l} ; 5.30 \pm 0.30$, nitrate; $19.20 \pm 0.20$ and total hardness; $475 \pm 4.80$ ) (Table 1).

\section{Microbiological Assessment}

The bacteriological load in the P. byronensis sampled from Fish Town River, lower Niger River Nigeria showed that there were variations in the occurrence of the different groups. Salmonella /Shigella count was highest $1.96 \pm 3.45 \mathrm{X} 103(\mathrm{cfu} / 100 \mathrm{~mL})$ followed by Total vibrio counts $1.66 \pm 3.13 \mathrm{X} 103(\mathrm{cfu} / 100 \mathrm{~mL})$. Total heterotrophic bacteria count was $1.63 \pm 4.97 \mathrm{X} 103(\mathrm{cfu} / \mathrm{m})$ and with least Coliform count, $1.30 \pm 3.70$ X 103 (cfu/100mL) (Table 2 and 3).

Table 2. Bacteriological load in P. byronensis sampled from fish Town River, lower

Niger River Nigeria during the wet season

\begin{tabular}{|c|c|c|c|c|}
\hline Samples stations & $\begin{array}{c}\text { Total } \\
\text { heterotrophic } \\
\text { bacteria counts } \\
(\mathrm{cfu} / \mathrm{ml}) \\
\left(\mathrm{X} \mathrm{10} \mathbf{1 0}^{\mathbf{3}}\right)\end{array}$ & $\begin{array}{c}\text { Coliform } \\
\text { counts } \\
(\text { cfu/100ml }) \\
\left(\times 1^{3}\right)\end{array}$ & $\begin{array}{c}\text { Salmonella/ } \\
\text { Shigella counts } \\
(\text { cfu/100ml }) \\
\left(\mathbf{X ~ 1 0}^{\mathbf{3}}\right)\end{array}$ & $\begin{array}{c}\text { Total vibrio counts } \\
(\mathrm{cfu} / \mathbf{1 0 0 \mathrm { ml } )} \\
\left(\mathrm{X} \mathrm{10} \mathbf{1 0}^{\mathbf{3}}\right)\end{array}$ \\
\hline Station A & $2.01 \pm 7.45$ & $1.20 \pm 5.20$ & $1.40 \pm 2.45$ & $1.10 \pm 3.20$ \\
\hline Station B & $1.70 \pm 2.68$ & $1.30 \pm 3.10$ & $1.80 \pm 4.70$ & $2.30 \pm 1.10$ \\
\hline Station $\mathrm{C}$ & $1.20 \pm 1.40$ & $1.40 \pm 2.10$ & $2.70 \pm 3.10$ & $1.60 \pm 2.10$ \\
\hline Mean \pm SE & $1.63 \pm 4.97$ & $1.30 \pm 3.70$ & $1.96 \pm 3.45$ & $1.66 \pm 3.13$ \\
\hline
\end{tabular}

The high Salmonella / Shigella species reported in this investigation is an indication of sewage contamination. Besides, they were higher than the EPA water standard for drinking water, which states that these pathogenic organisms must not be present in water. As they are of public health concerns, they have been linked with various infections such as new born meningitis and infantile diarrhea [19]. It is important to note that Salmonella species is food-borne pathogen and apart from human, it is also pathogenic to reptiles [21].

Total vibrio count (TVC) that was prevalent during the wet season in the Fish Town River could be attributed to the runoff from the seepage of toilets and the impact of the environment. This was due to the higher influence of the brackish environment that provokes the inactivation of the allochthonous microbiota from sewage discharges except for the halotolerant microorganisms' vibrio and staphylococci [22].

Table 3. Bacteriological load in P. byronensis sampled from fish Town River, lower

Niger River Nigeria during the dry season

\begin{tabular}{|c|c|c|c|c|}
\hline Samples stations & $\begin{array}{c}\text { Total } \\
\text { heterotrophic } \\
\text { bacteria counts } \\
(\mathrm{cfu} / \mathrm{ml}) \\
\left(\mathrm{X} \mathrm{10} \mathbf{1 0}^{\mathbf{3}}\right)\end{array}$ & $\begin{array}{c}\text { Coliform } \\
\text { counts } \\
(\text { cfu/100ml) } \\
\left(\mathbf{X} \mathbf{1 0}^{\mathbf{3}}\right)\end{array}$ & $\begin{array}{c}\text { Salmonella/ } \\
\text { Shigella counts } \\
\text { (cfu/100ml) } \\
\left(\times \mathbf{1 0}^{\mathbf{3}}\right)\end{array}$ & $\begin{array}{c}\text { Total vibrio counts } \\
(\mathrm{cfu} / \mathbf{1 0 0 \mathrm { ml } )} \\
\left(\mathrm{X} \mathrm{10} \mathbf{1 0}^{\mathbf{3}}\right)\end{array}$ \\
\hline Station A & $1.30 \pm 2.20$ & $1.20 \pm 1.10$ & $0.60 \pm 0.20$ & $0.50 \pm 3.20$ \\
\hline Station B & $1.10 \pm 1.40$ & $1.10 \pm 0.50$ & $0.10 \pm 0.13$ & ND \\
\hline Station C & $1.50 \pm 2.70$ & ND & ND & ND \\
\hline Mean \pm SE & $1.30 \pm 2.1$ & $0.76 \pm 0.53$ & $0.23 \pm 0.11$ & $0.17 \pm 0.06$ \\
\hline
\end{tabular}

The total heterotrophic bacteria counts were higher than the recommendation limit set by various regulatory bodies [23]. This is an indication of the existence of organic matter and dissolved minerals in the Rivers. These may be attributed to the faecal contamination from human settlement along the coastal 
stretch. Similarly, open defecation in rarely available land spaces in the riverine communities is a common practice, hence possibly due to this, high HPC was reported in this investigation.

The coliform count reported in the study may be an indication that the Rivers are contaminated with fecal materials [23]. Similar to the HPC, the total coliform counts which were remarkably present and above the EPA maximum contamination level (MCL) for coliform bacteria in water of zero total coliform per $100 \mathrm{ml}$ of water23. However, it was below the upper threshold for European Union class B classification (4,600 Escherichia coli CFU/100 g).

All the groups of investigated bacteria were detected during the wet season only as Coliform and Salmonella /Shigella were not observed in station C and Vibrio were not observed in station B and C during the dry season (Table 3). Similarly, the occurrence of the bacteria was more in wet season than in the dry season, with the highest occurrence of $1.96 \pm 3.45 \times 10^{3}(\mathrm{cfu} / 100 \mathrm{~mL})$ recorded in Salmonella /Shigella count (wet season), while the least of $0.17 \pm 0.06 \times 10^{3}$ (cfu/100Ml) recorded in total vibrio counts and was observed in dry season. The wet season (August-October) contained more bacteria loads than the dry season (November-January), which may be attributed to the anthropogenic factors and physico-chemical properties of the aquatic environment. It is well documented that human activities and oil pollution effects play a significant role in the influence the microbial qualities of aquatic environment. Benka-Coker and Ohimian [24] observed that increased human activities can easily influence the level of organic matter which can cause high microbial load. Besides, the introduction of waste water into water body also increased the amount of organic matter and essential nutrients, causing changes in the microflora [25].

\section{Proximate analysis}

The food shortage situation is more extreme with protein deficit when compared to the availability

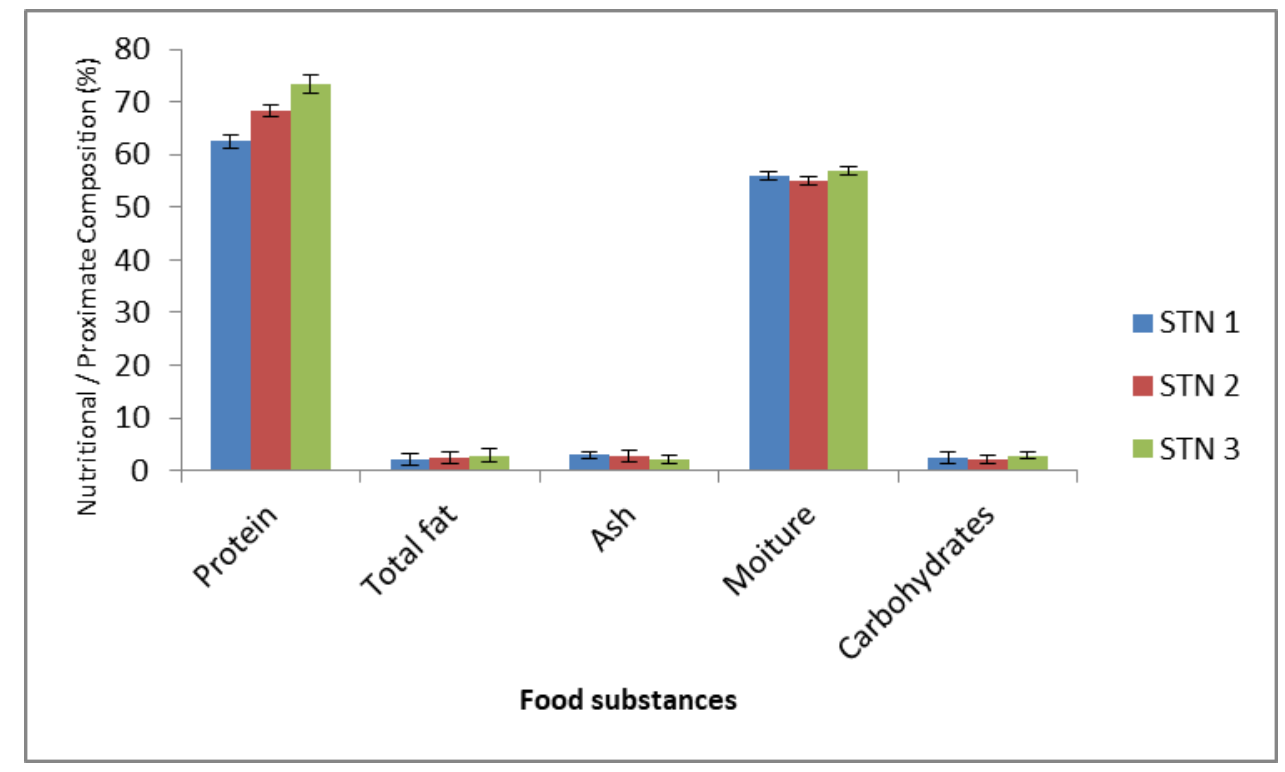

Figure 1. (A) The nutritional quality of P.byronensis tissue (edible part) from three stations within the fish Town Rivers Niger Delta Nigeria during the wet season (Means \pm SE) 


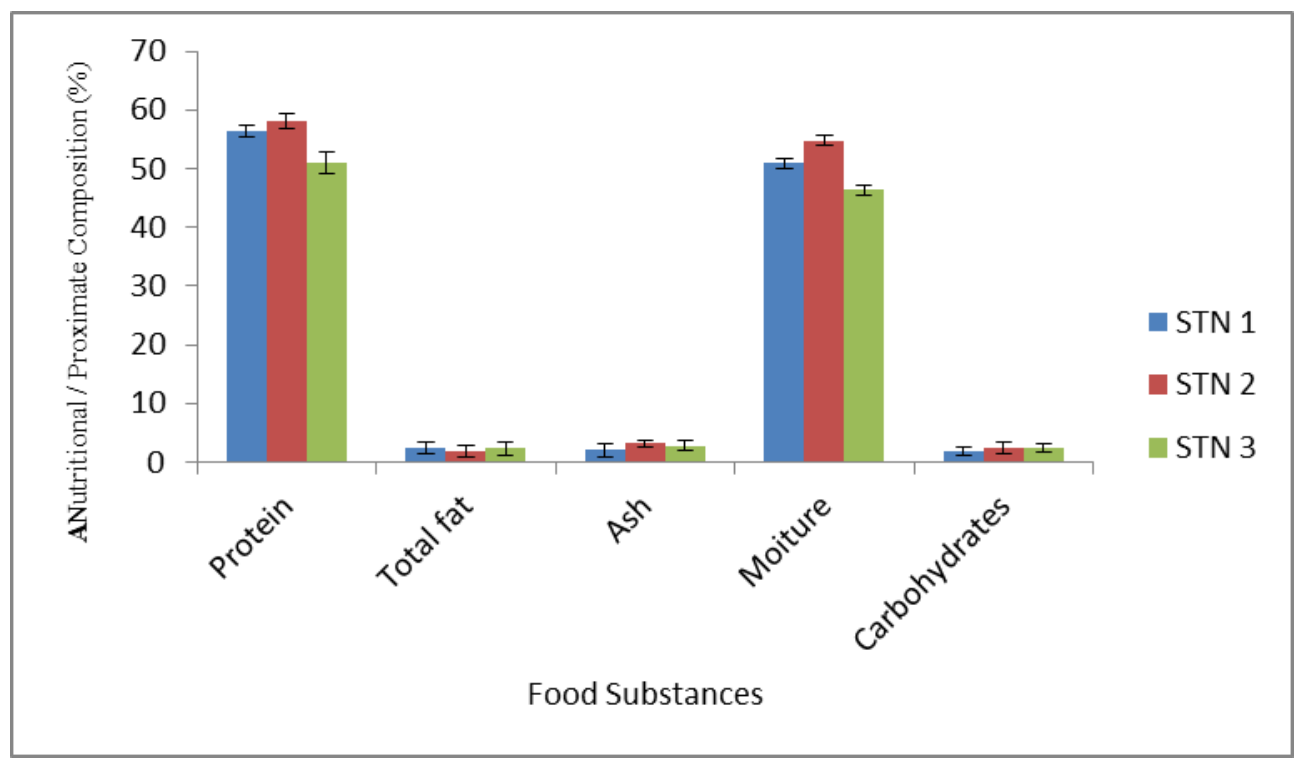

Figure 3. The nutritional quality of P.byronensis tissue (edible part) from three stations within the fish Town Rivers Niger Delta Nigeria during the dry season (Means \pm SE)

of carbohydrate and micro elements [26]. The proximate composition of P.byronensis from three selected stations within the Fish Town Rivers during the wet and dry season is shown in Figure 2 and 3.

No significant difference $(\mathrm{P}>0.05)$ in the nutritional composition between the stations was investigated. The large proportion of protein in the snail's meat was neither varies significantly with seasons nor in spatial distribution $(\mathrm{p}>0.05, \mathrm{~F}=9.70)$. These results were in agreement with the study of [27] with 88.37 percent crude protein, that was little higher than this investigation. Similarly, lower crude protein (18.3\%) was reported by [28] and (25.7\%) by [29] for Archachatina maginata snail.

Comparing with the other meat, snail meat had higher protein level than (18.3\%) crude protein value obtained from chicken meat and (19.6) from beef [30]. This is an indication that the protein content in this snail is higher than those found in the meat of other conventional livestock. This supports the assertion that snail meat contains protein, vitamin A, B6, B12, K, foliates, fat, iron, calcium, magnesium, phosphorus, copper and zinc [31]. The meat also has amino acids arginine and lysine at higher levels than in whole egg, plus essential fatty acids such as linoleic and linolenic acids, required for normal tissue development and maintenance [32].

The snail meat was high in moisture content (49\%), though lower than in beef $(63.90 \%)$ and chicken (69.40),but low in; carbohydrates (2.1\%), total fat (2.6\%) and ash (2.6\%). This indicates that the snail is a valuable source of sea food that will meet the balance nutritional needs of man.

\section{Conclusion}

The results of this study provided valuable information about $P$. byronensis, a dominant aquatic snail in the Niger Delta environment. The findings revealed that human activities may have influenced microbial load in the Rivers, and the nutritional status of snail revealed that it could be used as food for humans, which would go a long way in enhancing nutritional value of diet as the gastropod is very rich in protein and other necessary food requirements of man. 


\section{Contribution of Authors}

Ifeoma Vivian Anyiam, develop the concept and participate in the samplings and analysis of the data. Thomas Ohwofasa Ikpesu, liaised with the communities where samples were collected, and supported in the analysis, interpretation of data and take care of the correspondence.

\section{References}

[1] J. S. Diana (2009). Aquaculture production and biodiversity conservation. BioScience, 59: 27-38. doi.org/10.1525/bio.2009.59.1.7

[2] M. M. Dey (2015). World and U.S. demand and supply relationships for seafood:

Implications for aquaculture producers, Aquaculture Magazine, pp. 44-45.

[3] T.-K. Chiou, M.-M. Lai and C.-Y. Shiau (2001). Seasonal variations of chemical constituents in the muscle and viscera of small abalone fed different diets. Fisheries Science, 67: 146-156. doi.org/10.1046/j.1444-2906.2001.00211.x

[4] L. G. Linehan, T. P. O'connor and G. Burnell (1999). Seasonal variation in the chemical composition and fatty acid profile of Pacific oysters (Crassostrea gigas). Food Chem., 64: 211-214. doi.org/10.1016/S0308-8146(98)00144-7

[5] S. Dridi, M. S. Romdhane and M. Elcafsi (2007). Seasonal variation in weight and biochemical composition of the Pacific oyster, Crassostrea gigas in relation to the gametogenic cycle and environmental conditions of the Bizert Lagoon, Tunisia. Aquaculture, 263: 238-248. doi.org/10.1016/j.aquaculture.2006.10.028

[6] B. D. Mooney, P. D. Nichols and N. G. Elliott (2002). Seafood the Good Food II. Oil profiles for further Australian seafoods, and influencing factors. FRDC Project 99/331. Guide prepared for the Fisheries Research and Development Corporation, Australia.

[7] G. Srilatha, K. Chamundeeswari, K. Ramamoorthy, G. Sankar and D. Varadharajan (2013). Proximate, amino acid, fatty acid and minerals analysis of clam, Meretrix casta (Chemnitz) from Cuddalore and Parangipettai Coast, south east coast of India. J Mar Biol Oceanogr., 2.2. doi:10.4172/23248661.1000111

[8] K. R. Mahaffey (2004a). Fish and shellfish as dietary sources of methylmercury and the omega-3 fatty acids, eicosahexaenoic acid and docosahexaenoic acid: risks and benefits. Environ. Res., 95: 414-428.

[9] K. R. Mahaffey, R. P. Clickner and R. A. Jeffries (2008). Methylmercury and omega-3 fatty acids: Cooccurrence of dietary sources with emphasis on fish and shellfish. Environ. Res., 107: 20-29.

[10] A. P. Simopoulos (1991). Omega-3 fatty acids in health and disease and in growth and development. Am. J. Clin. Nutr., 54: 438-463.

[11] M. C. Milinsk, R. G. Padre, C. Hayashi, N. E. de Souza and M. Matsushita (2003). Influence of diets enriched with different vegetable oils on the fatty acid profiles of Helix aspersa maxima. Food Chem. 82: 553-558. doi.org/10.1016/S0308-8146(03)00010-4

[12] P.Vasconcelos, M. P. Gaspar, M.Castro and M. L. Nunes (2009). Influence of growth and reproductive cycle on the meat yield and proximate composition of Hexaplex trunculus (Gastropoda: Muricidae). J. Mar. Biol. Assoc. U. K., 89: 1223-1231.

[13] APHA (1998). Standard Methods for the Examination of Water and Wastewater, 20th Ed., American Public Health Association New York, USA.

[14] L. J. Maturin and J. T. Peeler (2001). Aerobic plate count. In L. Maturin \& J. T. Peeler. BAM: Bacteriological Analytical Manual (Chap. 3). Maryland: U.S. Food and Drug Administration. Retrieved from http://www.fda.gov/Food/FoodScienceResearch/LaboratoryMethods/ ucm063346.htm

[15] G. Holt, N. Krieg, P. Sneath, J. Staley and S. Williams (1994). Bergey’s Manual of Determinative of Bacteriology. 9th edition.Williams and Wilkins. USA. pp. 560-570.

[16] O. H. Lowry, N. J. Rosenbrough, A. L.Farr and R. J. Randall (1951). Protein measurement with Folin phenol reagent. J. Biol. Chem., 193: 265-275.

[17] J. Folch, M. Lees, G. H. Sloanes Stanley (1957). A simple method for the isolation and of total purification of lipids from animal tissues. J. Biol. Chem., 226: 497-509. 
[18] S. Rao (1990). A. A. O. A. C., Official methods of analysis of the association of analytical chemists.

[19] EPA, U. (2003). Environmental Protection Agency Safe Drinking Water Act. EPA 816-F-03-016.

[20] S.Water AND World Health Organization (2006). Guidelines for drinking-water quality [electronic resource]: incorporating first addendum. Vol. 1, Recommendations.

[21] EPA (2002). US Environment Protection Agency, Safe Drinking Water Act Ammendment http:// www. epa.gov/safe water $/ \mathrm{mcl}$. Html

[22] J. J. Borrego and M. J. Figueras (1997). Microbiological quality of natural waters. Microbiologia, 13: 413-426.

[23] M. O. Benka-Coker and E. I. Ohimian (1995). Investigation of spatial variation in bacterial distribution in surface waters of Ikpoba River. Nig. J. Microbiol., 10: 27-32.

[24] G. Rheinheimer (1992). Aquatic microbiology (No. 579.68 RHE).

[25] EPA (2002). US Environment Protection Agency, Safe Drinking Water Act

Ammendment http:// www. epa.gov/safe water/mcl. Html

[26] M. I. Osuinde and N. R. Eneuzie (1999). Bacteriological analysis of ground water. Nigeria J. Microbiol., 13: $47-54$.

[27] A. O. K. Adesehinwa and B. K. Ogunmodede (1995). Swine feeds and practical feed composition techniques. Paper Presented at National Agricultural Extension and Research Liaison Service. National pig production workshop, National Cereal Research Institute, Moor Plantation, Ibadan, April 3-7.

[28] E. A. Imevbore and A. A. Ademosun (1988). Nutritive value of the African Giant land snails, Archachatina marginata. J. Ani. Production and Research. 8: 76-87.

[29] O. O. Babalola and A. O. Akinsoyinu ( 2009). Proximate composition and mineral profile of snail meat from different breeds of land snail in Nigeria. Pak. J. Nutr., 8: 1842-1844.

[30] A. J. Adeola, A. I. Adeyemo, J. A. Ogunjobi, S. A, Alaye and K. M. Adelakun (2010). Effect of natural and concentrate diets on proximate composition and sensory properties of Giant Land Snail (Archachatina maginata) meat. Journal of Applied Sciences in Environmental Sanitation, 5: 185-189.

[31] FAO (1969). Food and Agricultural Organization Trade Books, Vol. 23, Rome, Italy

[32] S. U. Ukpong (2009). Snail (Archachatina marginata) pie: a nutrient-rich snack for schoolage children and young mothers. Int. J. Food Safety, Nutrition and Public Health, 2: 125-130. 